\title{
KEMAMPUAN DAYA LARVASIDA EKSTRAK DAUN ALPUKAT (Persea americana Mill.) TERHADAP Culex quinquefasciatus
}

\author{
Adhi Kumoro Setya ${ }^{1}$, Nia Lestyowati ${ }^{2}$ \\ ${ }^{1,2}$ Stikes Nasional Solo \\ Email: adhi.kumoro@stikesnas.ac.id
}

\begin{abstract}
Background:Culexquinquefasciatus is an important species of mosquito and one of serious pest if it is seen from the side of public health. Chemical management is an effective strategy that is widely used in the daily life. However, there are many negative consequences of its implementation. Among the biopesticides, avocado plants are appropriate to be a research candidate because they are rich in anti-insect phytochemicals.

Method: This research is an experimental test employing Post-test with Control study plan which result was processed by using probit analysis. There were eight variations of concentration $(0.1 \%, 0.05 \%, 0.025 \%, 0.0125 \%, 0.006 \%, 0.003 \%, 0.001 \%$ and $0.0007 \%)$ and each concentration was treated three times. Temefos was used as the positive control in this research. There were 10 instar larvae III used in each treatment.

Result:From the extract phytochemical result, alkaloid, flavonoid and saponin were found. The probit analysis shows lethal concentration (LC 90) on the concentration of $0.0316 \%$ and positive control on the concentration of $0.01 \%$. Temperature, humidity, and $\mathrm{pH}$ were in the safe limit for larvae, which were $23^{\circ} \mathrm{C}, 68 \%$ dan 6 , respectively.

Conclusion: The avocado leaf extract larvicide effectivity is at the concentration of $0.0314 \%$. This is still a bit higher than the positive control (temefos), which is at $0.01 \%$.
\end{abstract}

Keywords: Culex quinquefasciatus, avocado leaf, extract, larvicide

\section{PENDAHULUAN}

Nyamuk merupakan vector penting dari berbagai macam pathogen dan parasite medis serta penyakit hewan di seluruh dunia.Spesies penting dari nyamuk yang terkenal yaitu Culex quinquefasciatus muncul sebagai vector cerdas karena kemampuan adaptif, plastisitas ekologi, perilaku infasif, spesifisitas inang dan kemampuan reproduksi mereka yang tinggi ${ }^{1}$.

Culex quinquefasciatus menjadi vector parasite nematoda, protozoa dan virus yang beberapa diantaranya memicu penyakit berbahaya seperti ; filariasis, Japanese Encephalitis, St. Louis Encephalitis, Reticuloendotheliosis, malaria pada burung dan Chikungunya ${ }^{2}$.

Meditory | ISSN Online : 2549-1520, ISSN Cetak : 2338 - 1159, Vol. 6, No. 1, Juni 2018 
Berbagai produk dan perangkat sintetis yang dirancang untuk mengendalikannya tidak berhasil karena munculnya resistensi yang dikembangkan oleh berbagai spesies nyamuk. Sebagian besar target program pengendalian nyamuk dilakukan pada stadium larva, karena adultisida hanya dapat mengurangi populasi stadium dewasa untuk sementara ${ }^{3}$.

Meluasnya penggunaan insektisida sintetis telah menyebabkan banyak konsekuensi negatif, seperti memiliki toksisitas tinggi terhadap mamalia sehingga membatasi keberhasilan pengaplikasiannya untuk pengendalian vektor ${ }^{4}$. Oleh karena itu ada kebutuhan mendesak ditemukanya alternatif yang lebih aman, lebih ramah lingkungan dan efisien yang memiliki potensi untuk menggantikan pestisida sintetis.

Di antara biopestisida, banyak penelitian menggunakan tanaman karena sifat eko-toksikologinya. Berbagai riwayat menunjukan penggunaan metabolit sekunder tanaman untuk membunuh atau sekedar mengusir serangga banyak dilakukan dalam skala rumah.

Penelitian ini dirancang untuk menguji kemampuan ekstrak daun alpukat (Persea americana Mill.) sebagai larvasida terhadap Culexq uinquefasciatus.

\section{METODE}

Penelitian ini merupakan penelitian eksperimental dengan rancangan studi Post-test With Control. Subyek dari penelitian ini adalah larva instar III Culexq uinquefasciatus hasil koloni dari laboratorium Parasitologi Fakultas Kedokteran Universitas Gadjah Mada Yogyakarta.

\section{Bahan}

Persiapan ekstrak tanaman

Daun alpukat (Persea americana Mill.) dikumpulkan dari kebun penduduk kabupaten Sukoharjo provinsi Jawa Tengah. Daun dikeringkan pada suhu kamar dan dihaluskan menjadi serbuk lalu dipindahkan ke dalam gelas kaca untuk ekstraksi. Secara singkat, 500 g serbuk daun dimaserasi dengan etanol perbandingan (1:10) selama 3 hari. Suspensi kemudian disaring dievaporasi menggunakan vakum rotary dan disimpan sebagai produk hasil ekstraksi sebelum digunakan.

\section{Tahapan}

Persiapan Larva Instar III

Larva instar III diperoleh dari laboratorium Parasitologi Fakultas Kedokteran Universitas Gadjah Mada Yogyakarta. Sebanyak 500 larva 
Adhi Kumoro Setya dan Nia Lestyowati, Kemampuan Daya Larvasida Ekstrak Daun Alpukat (Persea americana mill.) terhadap Culex quinquefasciatus

dimasukkan dalam aquades 1 (satu) liter.

Dipilih dan dipisahkan larva instar III dalam cup masing-masing 10 ekor tiap cup. Sebagai kontrol positif dalam penelitian ini menggunakan temofos.

\section{Persiapan konsentrasi ekstrak}

Konsentrasi yang diuji dalam penelitian ini berurutan dari $0,1 \%, 0,05 \%$, $0,025 \%, \quad 0,0125 \%, \quad 0,006 \%, \quad 0,003 \%$, $0,001 \%$ dan $0,0007 \%$. Tiap konsentrasi dilakukan pengulangan sebanyak 3 (tiga) kali berdasar rumus Federer. Volume aquades sebagai pelarut dan pengujian digunakan $100 \mathrm{ml}$ tiap cup. Sebagai control hanya berisi aquades tanpa ekstrak.
Pengujian larvasida

Tiap konsentrasi berikut pengulangannya, kepada masing-masing cup dimasukan 10 ekor larva instar III. Efek mortalitas ekstrak dibaca selama 24 jam paparan. Lethal concentration (LC90) dari konsentrasi ekstrak dihitung menggunakan analisis probit.

\section{HASIL DAN PEMBAHASAN}

Dari hasil memperlihatkan bahwa semakin meningkat konsentrasi dari ekstrak yang diberikan maka jumlah larva yang mengalami mortalitas juga semakin banyak. Hal tersebut terjadi pada semua prosedur pengulangan dari konsentrasi (tabel 1 dan gambar 1). 
Tabel 1.

Hasil Uji larvasida Ekstrak Daun Alpukat

\begin{tabular}{|c|c|c|c|c|c|c|c|c|c|}
\hline \multirow[t]{2}{*}{$\begin{array}{c}\text { Konsentrasi } \\
(\%)\end{array}$} & \multirow[t]{2}{*}{ Ulangan } & \multirow[t]{2}{*}{$\begin{array}{c}\text { Jumlah } \\
\text { Jentik }\end{array}$} & \multirow[t]{2}{*}{$\begin{array}{c}\text { Kematian } \\
24 \text { jam }\end{array}$} & \multicolumn{2}{|c|}{$\begin{array}{c}\text { Kelembaban } \\
\text { ruang }\end{array}$} & \multicolumn{2}{|c|}{ Suhu Air ${ }^{\circ} \mathrm{C}$} & \multicolumn{2}{|c|}{ pH Air } \\
\hline & & & & pre & post & pre & post & pre & post \\
\hline \multirow[t]{3}{*}{0,00078125} & 1 & 10 & 0 & $66 \%$ & $68 \%$ & $23^{\circ} \mathrm{C}$ & $23^{\circ} \mathrm{C}$ & 6 & 6 \\
\hline & 2 & 10 & 0 & $66 \%$ & $68 \%$ & $23^{\circ} \mathrm{C}$ & $23^{\circ} \mathrm{C}$ & 6 & 6 \\
\hline & 3 & 10 & 0 & $66 \%$ & $68 \%$ & $23^{\circ} \mathrm{C}$ & $23^{\circ} \mathrm{C}$ & 6 & 6 \\
\hline \multirow[t]{3}{*}{0,0015625} & 1 & 10 & 1 & $66 \%$ & $68 \%$ & $23^{\circ} \mathrm{C}$ & $23^{\circ} \mathrm{C}$ & 6 & 6 \\
\hline & 2 & 10 & 1 & $66 \%$ & $68 \%$ & $23^{\circ} \mathrm{C}$ & $23^{\circ} \mathrm{C}$ & 6 & 6 \\
\hline & 3 & 10 & 0 & $66 \%$ & $68 \%$ & $23^{\circ} \mathrm{C}$ & $23^{\circ} \mathrm{C}$ & 6 & 6 \\
\hline \multirow[t]{3}{*}{0,003125} & 1 & 10 & 2 & $66 \%$ & $68 \%$ & $23^{\circ} \mathrm{C}$ & $23^{\circ} \mathrm{C}$ & 6 & 6 \\
\hline & 2 & 10 & 3 & $66 \%$ & $68 \%$ & $23^{\circ} \mathrm{C}$ & $23^{\circ} \mathrm{C}$ & 6 & 6 \\
\hline & 3 & 10 & 3 & $66 \%$ & $68 \%$ & $23^{\circ} \mathrm{C}$ & $23^{\circ} \mathrm{C}$ & 6 & 6 \\
\hline \multirow[t]{3}{*}{0,00625} & 1 & 10 & 5 & $66 \%$ & $68 \%$ & $23^{\circ} \mathrm{C}$ & $23^{\circ} \mathrm{C}$ & 6 & 6 \\
\hline & 2 & 10 & 6 & $66 \%$ & $68 \%$ & $23^{\circ} \mathrm{C}$ & $23^{\circ} \mathrm{C}$ & 6 & 6 \\
\hline & 3 & 10 & 5 & $66 \%$ & $68 \%$ & $23^{\circ} \mathrm{C}$ & $23^{\circ} \mathrm{C}$ & 6 & 6 \\
\hline \multirow[t]{3}{*}{0,0125} & 1 & 10 & 7 & $66 \%$ & $68 \%$ & $23^{\circ} \mathrm{C}$ & $23^{\circ} \mathrm{C}$ & 6 & 6 \\
\hline & 2 & 10 & 7 & $66 \%$ & $68 \%$ & $23^{\circ} \mathrm{C}$ & $23^{\circ} \mathrm{C}$ & 6 & 6 \\
\hline & 3 & 10 & 6 & $66 \%$ & $68 \%$ & $23^{\circ} \mathrm{C}$ & $23^{\circ} \mathrm{C}$ & 6 & 6 \\
\hline \multirow[t]{3}{*}{0,025} & 1 & 10 & 9 & $66 \%$ & $68 \%$ & $23^{\circ} \mathrm{C}$ & $23^{\circ} \mathrm{C}$ & 6 & 6 \\
\hline & 2 & 10 & 8 & $66 \%$ & $68 \%$ & $23^{\circ} \mathrm{C}$ & $23^{\circ} \mathrm{C}$ & 6 & 6 \\
\hline & 3 & 10 & 8 & $66 \%$ & $68 \%$ & $23^{\circ} \mathrm{C}$ & $23^{\circ} \mathrm{C}$ & 6 & 6 \\
\hline \multirow[t]{3}{*}{0,05} & 1 & 10 & 9 & $66 \%$ & $68 \%$ & $23^{\circ} \mathrm{C}$ & $23^{\circ} \mathrm{C}$ & 6 & 6 \\
\hline & 2 & 10 & 10 & $66 \%$ & $68 \%$ & $23^{\circ} \mathrm{C}$ & $23^{\circ} \mathrm{C}$ & 6 & 6 \\
\hline & 3 & 10 & 10 & $66 \%$ & $68 \%$ & $23^{\circ} \mathrm{C}$ & $23^{\circ} \mathrm{C}$ & 6 & 6 \\
\hline \multirow[t]{3}{*}{0,1} & 1 & 10 & 10 & $66 \%$ & $68 \%$ & $23^{\circ} \mathrm{C}$ & $23^{\circ} \mathrm{C}$ & 6 & 6 \\
\hline & 2 & 10 & 10 & $66 \%$ & $68 \%$ & $23^{\circ} \mathrm{C}$ & $23^{\circ} \mathrm{C}$ & 6 & 6 \\
\hline & 3 & 10 & 10 & $66 \%$ & $68 \%$ & $23^{\circ} \mathrm{C}$ & $23^{\circ} \mathrm{C}$ & 6 & 6 \\
\hline \multirow[t]{3}{*}{ Kontrol (-) } & 1 & 10 & 0 & $66 \%$ & $68 \%$ & $23^{\circ} \mathrm{C}$ & $23^{\circ} \mathrm{C}$ & 6 & 6 \\
\hline & 2 & 10 & 0 & $66 \%$ & $68 \%$ & $23^{\circ} \mathrm{C}$ & $23^{\circ} \mathrm{C}$ & 6 & 6 \\
\hline & 3 & 10 & 0 & $66 \%$ & $68 \%$ & $23^{\circ} \mathrm{C}$ & $23^{\circ} \mathrm{C}$ & 6 & 6 \\
\hline \multirow[t]{3}{*}{ Kontrol (+) } & 1 & 10 & 10 & $66 \%$ & $68 \%$ & $23^{\circ} \mathrm{C}$ & $23^{\circ} \mathrm{C}$ & 6 & 6 \\
\hline & 2 & 10 & 10 & $66 \%$ & $68 \%$ & $23^{\circ} \mathrm{C}$ & $23^{\circ} \mathrm{C}$ & 6 & 6 \\
\hline & 3 & 10 & 10 & $66 \%$ & $68 \%$ & $23^{\circ} \mathrm{C}$ & $23^{\circ} \mathrm{C}$ & 6 & 6 \\
\hline
\end{tabular}

Meditory | ISSN Online : 2549-1520, ISSN Cetak : 2338 - 1159, Vol. 6, No. 1, Juni 2018

HIm. 1-7, http://ejournal.poltekkes-denpasar.ac.id/index.php/M 
Tabel 2.

Kandungan Senyawa Aktif Ekstrak Daun Alpukat

\section{Hasil fitokimia kualitatif}

$\begin{array}{ll}\text { Ekstrak daun alpukat } & \text { Alkaloid } \\ & \text { Saponin }\end{array}$

Flavonoid

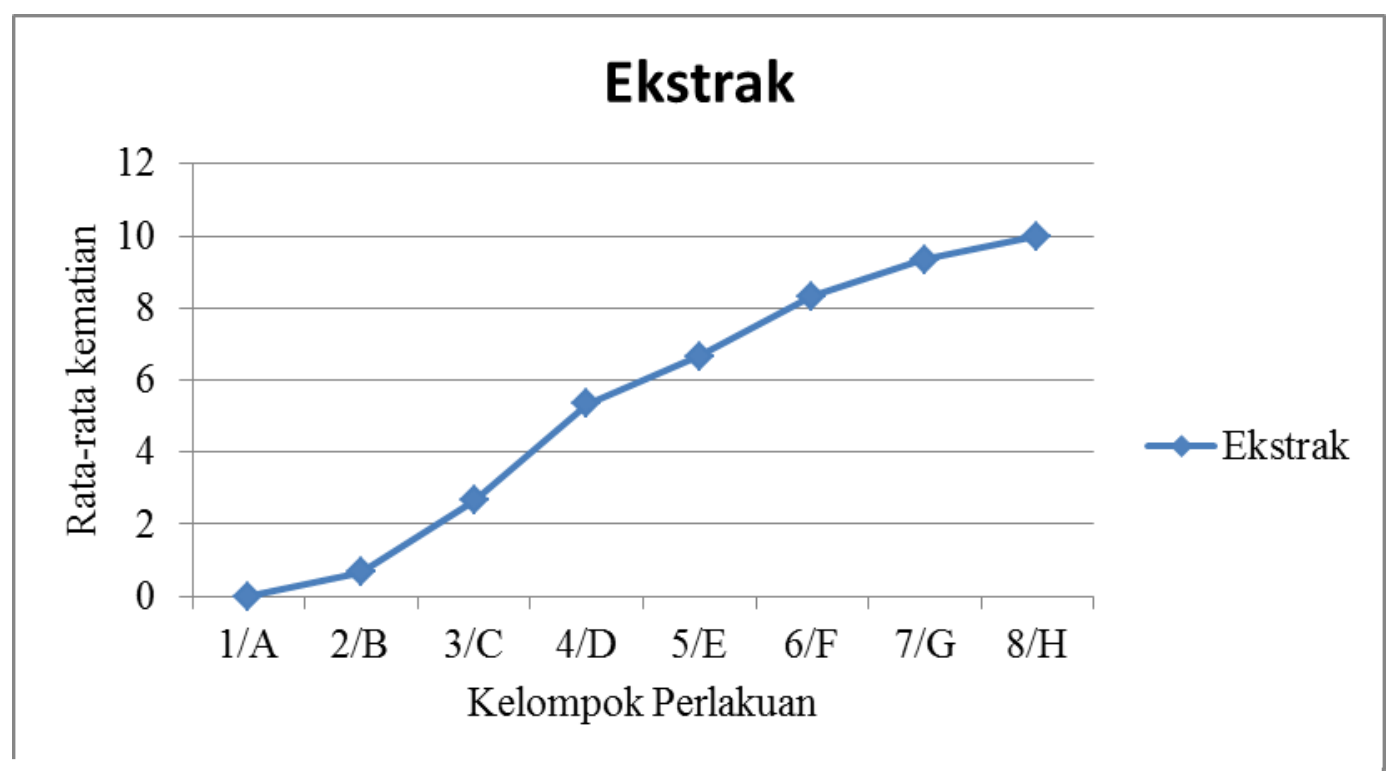

Gambar 1. Grafik Prosentase Ekstrak Daun Alpukat Terhadap Kematian Larva Culex quinquefasciatus

Keterangan :

1 : ekstrak daun alpukat dengan konsentrasi $0,00078125 \%$

2 : ekstrak daun alpukat dengan konsentrasi 0,0015625\%

3 : ekstrak daun alpukat dengan konsentrasi $0,003125 \%$

4 : ekstrak daun alpukat dengan konsentrasi $0,00625 \%$

5 : ekstrak daun alpukat dengan konsentrasi $0,0125 \%$

6 : ekstrak daun alpukat dengan konsentrasi $0,025 \%$

7 : ekstrak daun alpukat dengan konsentrasi $0,05 \%$

8 : ekstrak daun alpukat dengan konsentrasi $0,1 \%$

Hasil dari analisis probit lebih tinggi konsentrasinya dibandingkan memperlihatkan Lethal concentration dengan kontrol positif (temefos) yaitu (LC90) dari uji ini terjadi pada konsentrasi $\quad 0,01 \%$. Faktor-faktor yang dapat ekstrak $0,0314 \%$. Hasil ini masih sedikit mempengaruhi perkembangan dan

Meditory | ISSN Online : 2549-1520, ISSN Cetak : 2338 - 1159, Vol. 6, No. 1, Juni 2018

HIm. 1-7, http://ejournal.poltekkes-denpasar.ac.id/index.php/M 
kehidupan larva Culex quinquefasciatus, antara lain suhu air yang berkisar antara 20-30 ${ }^{0} \mathrm{C}$ dan kelembaban udara berkisar 60-80\%. Kondisi tersebut merupakan keadaan dimana nyamuk mengalami perkembangan secara optimal. Pada saat penelitian dapat dilihat hasil pengukuran yang telah dilakukan, kelembaban udara berkisar 66-68\% dan suhu air pada kelompok kontrol dan perlakuan adalah $23^{0} \mathrm{C}$, hal ini berarti kelembaban dan suhu air yang digunakan berada dalam kondsi normal untuk kehidupan larva nyamuk Culex quinquefasciatus.

Hasil pH air yang didapatkan yaitu 6, dimana $\mathrm{pH}$ air dalam kondisi sedikit asam. Larva dapat hidup dengan $\mathrm{pH}$ air 5,8-8,6. Pada penelitian ini $\mathrm{pH}$ masih normal untuk kehidupan larva nyamuk ${ }^{9}$.

Berdasarkan tabel 2 dapat diketahui kandungan senyawa kimia yang berada di dalam ekstrak daun alpukat terdiri dari alkaloid, saponin, dan flavonoid. Alkaloid dalam daun bisa mendegradasi dinding sel masuk ke dalam dan merusak sel ${ }^{5}$. Saponin bersifat sebagai antimikroba dan bersifat sangat toksik bagi serangga. Saponin

\section{DAFTAR PUSTAKA}

1. Sajal Bhattacharya, ProbalBasu. 2016. he Southern House Mosquito, Culex quinquefasciatus: profile of a smart vector. Journal of mengandung bagian yang bersifat hormonal dari golongan steroid yang dapat berpengaruh dalam pertumbuhan larva ${ }^{6}$. Saponin juga merupakan surfaktan alami dengan sifat dapat menurunkankan tegangan permukaan pada dinding sel larva $^{7}$ dan menjadi racun perut ${ }^{8}$. Flavonoid digunakan sebagai bahan aktif dalam pembuatan insektisida nabati yang bekerja dengan cara menimbulkan kelayuan pada syaraf. Flavonoid juga dapat menjadi inhibitor bagi pernafasan larva nyamuk ${ }^{7}$.

\section{SIMPULAN DAN SARAN}

Dari hasil penelitian dapat disimpulkan bahwa ekstrak daun alpukat berpotensi sebagai larvasida. Dengan konsentrasi $0,0314 \%$ dari ekstrak sudah mampu menghasilkan lethal concentration (LC90). Dari hasil penelitian ini perlu diteliti lagi daya larvasida terhadap nyamuk spesies lain dan kemampuan bioinsektisida kepada stadium telur dan dewasanya. Dapat juga penelitian ini dikembangkan menggunakan pelarut jenis lain.

Entomology and Zoology Studies. 4(2): 73-81

2. Olajide J. Afolabi, Iyabo A. Simon-Oke, Oluwadoyinsolami O. Elufisan, Mobolanle O. Oniya. 
2017. Adulticidal and repellent activities of some botanical oils against malaria mosquito: Anopheles gambiae (Diptera: Culicidae). Department of Biology, Federal University of Technology Akure, Ondo State, Nigeria.

3. Veena Prajapati, A.K. Tripathi*, K.K. Aggarwal, S.P.S. Khanuja. 2005. Insecticidal, repellent and oviposition-deterrent activity of selected essential oils against Anopheles stephensi, Aedes aegypti and Culex quinquefasciatus. Bioresource Technology. Central Institute of Medicinal and Aromatic Plants, P.O. CIMAP, Lucknow, India.

4. Safia Zoubiri, Aoumeur Baaliouamer. 2011. Potentiality of plants as source of insecticide principles. Journal of Saudi Chemical Society. King Saud University.

5. Nopianti, Surya., Astuti, Dwi., Darnoto, Sri. 2008. Efektivitas Buah Belimbing Wuluh (Averrhoa bilimbi L.) Untuk Membunuh Larva Nyamuk Anopheles aconitus Instar III. Jurnal Kesehatan ISSN Vol.1 (2): 103-114
6. Irwan, Azidi., Komari, Noer., Rusdiana. 2007. Uji Aktivitas Saponin Fraksi n-Butanol Dari Kulit Batang Kemiri (Aleurites moluccana Willd.) Pada Larva Nyamuk Aedes aegypti. Jurnal Sains dan Terapan Kimia Vol 1 (2) : 93-101

7. Shadana, Meidy., Lesmana, Suri Dwi., Hamidy, M Yulis. 2014. Efek Larvasida Ekstrak Etanol Daun Pepaya (Carica papaya) Terhadap Larva Aedes aegypti. Universitas Riau

8. Haditomo, Indriantoro. 2010. Efek Larvasida Ekstrak Daun Cengkeh (Syzygium aromaticum L.) Terhadap Aedes aegypti L. Uiversitas Sebelas Maret Surakarta

9. Pratama, Bangkit Ary., Astuti, Dwi., Ambarwati. 2009. Pemanfaatan Ekstrak Daun Pandan Wangi (Pandanus amaryllifolius Roxb.) Sebagai Larvasida Alami. Jurnal Kesehatan, ISSN Vol. 2 (2) : 115-124 